\title{
Presentation and interpretation of structural data from the Nagssugtoqidian orogen using a GIS platform: general trends and features
}

\author{
Jeroen A.M. van Gool and Sandra Piazolo
}

\begin{abstract}
In this contribution we present data collected by more than 50 international geologists involved in geological mapping and research projects in the N agssugtogidian orogen of W est Greenland, organised by the G eological Survey of D enmark and Greenland and the D anish Lithosphere C entre. U sing a geographical information system (GIS) as a framework for visualisation and analysis of structural and lithological data, it is now possible to give a unique overview of thousands of data points, employed here within a study area of approximately $160 \times 180 \mathrm{~km}$ in the central and northern Nagssugtogidian orogen. The GIS methodology allows comparison, integration and analysis of datasets in terms of subject, space, and scale. This is extremely helpful in the recognition of geological patterns, such as terrain or domain boundaries and map-scale structures. Analysis of the available structural data shows clear differences in deformation patterns between the core and the northern segment of the $\mathrm{N}$ agssugtogidian orogen. $\mathrm{O}$ ne of the most prominent features is the EN E-striking N ordre Strømfjord shear zone, which transects the orogen from the coast to the Inland Ice. The data also clearly document a change from predominantly steeply dipping, EN E-W SW -trending fabrics and large, elongate structural domains in the core of the orogen, to large, open fold patterns and moderately to shallowly dipping fabrics in smaller structural domains in the north.
\end{abstract}

Keywords: geographical information systems, Nagssugtogidian orogen, West G reenland, structural data, structural domains

\footnotetext{
J.A.M .v.G \& \& S.P., G eological Survey of D enmark and Greenland, $\varnothing$ ster Voldgade 10, D K-1350 Copenhagen K, D enmark. E-mail: jvg@geus.dk

S.P., Geological Survey of D enmark and Greenland, $\varnothing$ ster Voldgade 10, D K-1350 Copenhagen K, D enmark. Present address: D epartment of G eology and G eochemistry, Stockholm University, 10691 Stockholm, Sweden.
}

$\mathrm{O}$ ver the past ten years the $\mathrm{N}$ agssugtoqidian orogen in central West Greenland (Fig. 1) has been the subject of intense geological research, involving both bedrock mapping and research into the Palaeoproterozoic and Archaean tectonic evolution of the region. This has led to a major improvement in the understanding of the tectonic development of the $\mathrm{N}$ agssugtoqidian orogen (Kalsbeek \& N utman 1996; Connelly et al. 2000; van G ool et al. 2002). The research was undertaken in two projects, organised by the Danish Lithosphere C entre (D LC) from 1994 to
1999 and the G eological Survey of D enmark and G reenland (GEUS) from 2000 to 2003, respectively. Approximately 35 international geologists from institutions on three continents participated in the field work of these projects, with changing teams from year to year. D uring these projects a very large amount of data was collected, including structural measurements, lithological observations, intrusive relationships, information about metamorphic mineral assemblages, etc. 0 ther structural data were collected during previous work in part of the region in 


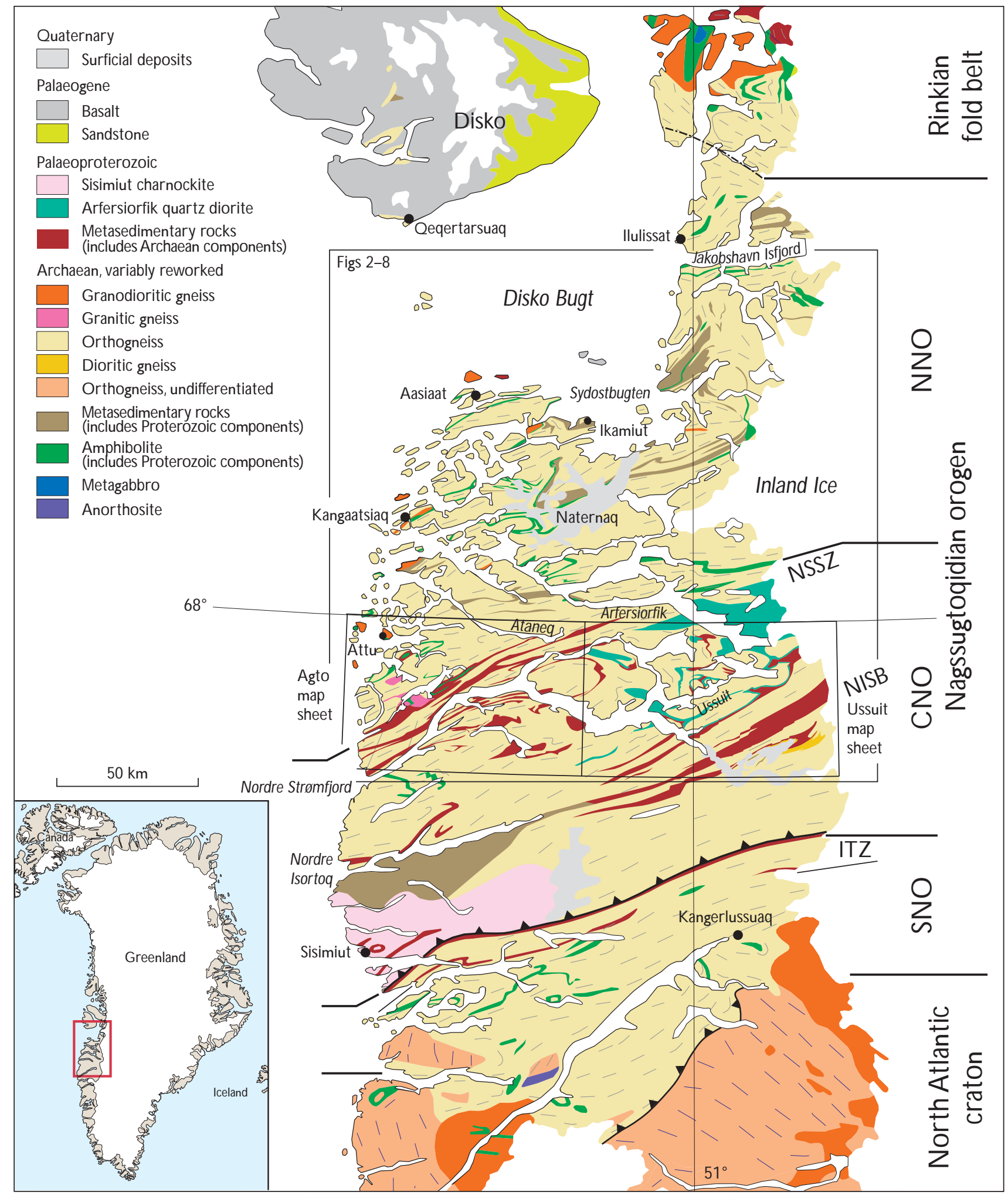

Fig. 1. Schematic geological map of central W est Greenland (modified from van Gool et al. 2002), depicting the N agssugtogidian orogen. IT Z, Ikertôq thrust zone; N ISB, N ordre Isortoq steep belt; N SSZ, Nordre Strømfjord shear zone; SN O , C N O and N N O, respectively, the southern, central and northern Nagssugtoqidian orogen. Small boxes outline the locations of the Agto and U ssuit map sheets; Large box indicates the location of Figs 2-8. 
the 1960 s and 1970s by the former G eological Survey of Greenland (GGU, now part of GEUS). Part of this was used by the collectors in their individual research or in small groups, and for the compilation of a published geological map, H owever, to date only a fraction of the total dataset has been made accessible in publications, and most of the original data collected prior to 2001 are only available for further analysis if extracted from the individual geologists' field diaries and field maps. With traditional methods it would be highly impractical and tedious to obtain an overview of all the structural data collected over time from the $\mathrm{N}$ agssugtogidian orogen in West Greenland, and a rigorous conventional analysis of the complete dataset would be close to impossible. H ence, alternative methods of data compilation and analysis were required.

Since 2001 GEUS' mapping projects have included systematic collection of structural data which are available digitally. The data from all participants are recorded in field diaries and on maps, stored electronically in spreadsheets, and subsequently entered in a geographical information system (GIS) for further presentation and analysis. In this way all data from an entire group of geologists can be accessed as a whole and used for map production and data analysis.

GIS methods has al ready proved useful in several disciplines including mineral exploration on local to global scales (e.g. Bonham-C arter et al. 1990; Goodwin et al. 1996; Knox-Robinson \& Wyborn 1997; Harris et al. 2001), palaeontology (e.g. Carrasco \& Barnosky 2000), and environmental assessment (e.g. True et al. 1999; Books 2000; Wilson et al. 2000).

In this paper we demonstrate the application of GIS data management, visualisation and methods of analysis in a large-scale and long-term international project, including data from two previous mapping projects in the region. We present for the first time in a digital format a set of more than 10000 structural orientation measurements and observations collected by more than 50 geologists in the Nagssugtogidian orogen over a period of 40 years. Such a presentation can (a) provide a very helpful overview of the data itself, (b) help to identify where future research efforts may be scientifically interesting, and (c) show how these together with geological and geophysical maps can define structural domains and illustrate the large-scalestructural variations through an important part of the orogen.

\section{The Nagssugtoqidian orogen}

The N agssugtogidian orogen in West Greenland is a Palaeoproterozoic collisional belt, dominated by Archaean gneisses that were reworked at amphibolite and granulitefacies during the Palaeoproterozoic orogeny (van Gool et al. 2002). It forms the northern boundary of the $N$ orth Atlantic craton in southern Greenland, and is bound to the north by the contemporaneous Rinkian fold belt. It consists of threetectonic segments, referred to as the southern, central and northern N agssugtogidian orogen (SN O, $\mathrm{CNO}$ and $\mathrm{NNO}$; Fig. 1), which respectively consist of a southern parautochthonous foreland, a high-grade core, and a transition zone to the Rinkian fold belt. Juvenile Palaeoproterozoic magmatic arc rocks and supracrustal sequences occur mainly in narrow belts within the $\mathrm{CN} O$. The Nagssugtogidian orogen is characterised by a dominant EN E-W SW structural trend, which culminates in a number of linear belts: the I kertôq thrust zone, the N ordre Isortoq steep belt, and the N ordre Strømfjord shear zone. These are interpreted as crustal-scale structures and alternate with areas dominated by large fold structures. $D$ etailed investigations in the core of the orogen have shown that during the Nagssugtogidian orogeny this region originally underwent a phase of $\mathrm{N} \mathrm{W}$-vergent thrusting, followed by folding now recognised predominantly as isoclinal folds (van Gool et al. 2002). A second fold phase resulted in upright, EN E-trending folds on a scale of tens of kilometres, with associated development of extension lineations plunging shallowly EN E. Finally, a phase of sinistral strike-slip shearing on the steep flanks of the large fold structures resulted in the above mentioned prominent linear belts. It is therefore only the latest deformation phases that generated the main EN E-W SW -trending tectonic fabric of the orogen (van Gool et al. 2002).

The area discussed in this study extends from $67^{\circ} \mathrm{N}$ in the N ordre Strømfjord region to $69^{\circ} 10^{\prime} \mathrm{N}$ at Jakobshavn I sfjord and covers the northern part of the $\mathrm{CN} O$ and most of the N N O (Fig. 1).

\section{Structural data}

\section{0 rigin of the data}

The structural data have been derived from two different sources. The data north of $68^{\circ} \mathrm{N}$ were collected during recent GEU S mapping projects (2001-2003), while the data from south of $68^{\circ} \mathrm{N}$ have been extracted from published GGU and GEUS maps, collected during previous GGU, D LC and GEU S projects. During the recent GEUS 
mapping projects, data were collected in the northern $\mathrm{N}$ agssugtogidian orogen. Structural measurements and other geological data were noted in field diaries together with their geographical coordinates using global positioning system (GPS) receivers. These data were subsequently entered in spreadsheets and imported into ArcView ${ }^{\circledR}$. T he geographical distribution of the structural data reflects the way they were collected along shorelines and on inland traverses. There may be several measurements at any one location, whereas no data were obtained in areas between traverses (which were often located many kilometres apart). In this study, we have restricted our analysis to the structural measurements. H owever, a combination of these data with other information, e.g. lithological and geophysical data, would makethis GIS-based analysis tool even morepowerful.

The southern part of the study area, south of $68^{\circ}$, is covered by two 1:100 000 scale maps, which were compiled prior to the digital storage of field data. The Agto map sheet in the west (O lesen 1984) consists of analogue data (but was recently digitised), whereas the $U$ ssuit map sheet in the east was produced in digital format (Fig. 1; van $\mathrm{Gool} \&$ M arker 2004). The structural data from the Agto and U ssuit map sheets are stored in GEU S' G eogreen map database and were extracted from this for the present study. H owever, these structural data only represent a fraction of the original data collected in the field. D uring the map compilations, the original structural data recorded on field maps or noted field diaries werefiltered such that only representative measurements were shown on the final map; each measurement typically covers an area of a few square kilometres. Thus, the southern part of the data compilation map in this paper shows an even distribution of data, and a much lower data density, compared to the more recently compiled areas in the north. The fact that the Agto map sheet only contains very few lineation measurements compared to the surrounding regions also reflects a change in focus sincethe 1960 s and 1970 s, when measurement of lineations was not considered a high priority. A large gap in the data coverage occurs in the east, from Arfersiorfik fjord to the north almost up to Sydostbugten (Fig. 1); this area was not covered by the mapping programmes by GGU and GEUS.

\section{D efinition of terms}

In the descriptions below the general orientation of a structural element is its three-dimensional orientation with respect to true north and horizontal, as defined by the combination of strike, dip direction and dip for planar

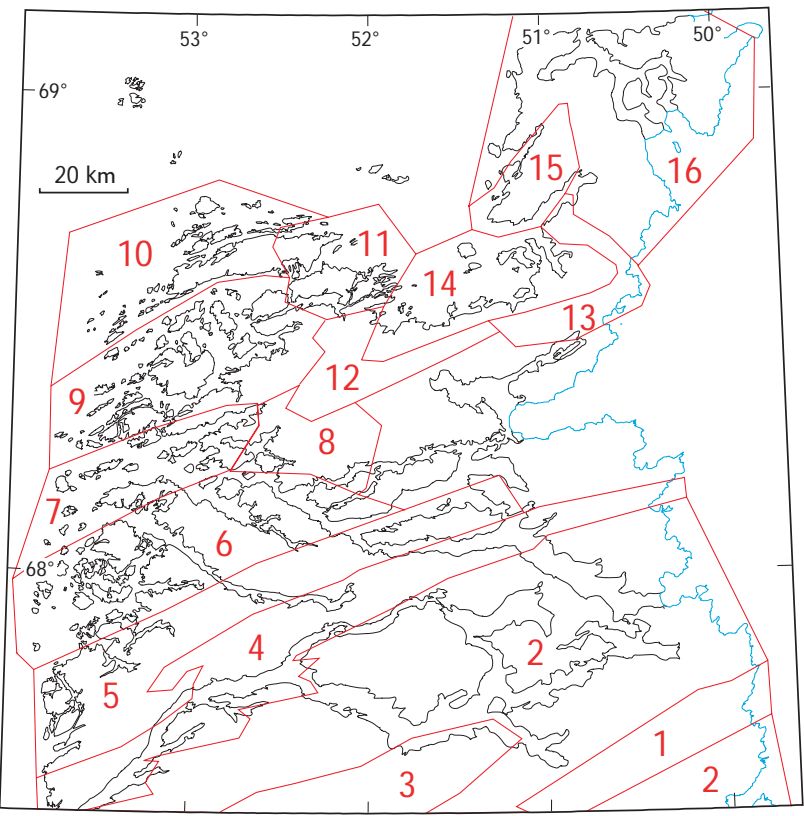

Fig. 2. Structural domains in the central and northern Nagssugtoqidian orogen, based on structural orientation data. Domain numbers refer to those used in Table 1, Fig. 8, and the main text.

structures, and plunge direction and plunge for linear structures. the term trend is used as the direction along the strike of a planar structure (without indication of dip direction), or the direction of plunge of a linear structure, without distinction between plunges up or down this direction. The trend is always expressed as two opposite directions (e.g. NE-SW ).

\section{Methods of data presentation}

For map presentation of the data we have used ArcView ${ }^{\circledR}$ version 3.2. In addition, stereographic projections and statistical analysis for the determination of great circles and point maxima were prepared with StereoN ett (J. D uyster, unpublished freeware). O nce the structural dataset has been incorporated into the GIS database, the ArcView ${ }^{\circledR}$ Geoprocessing extension can be used to easily select subsets of data in areas with irregular shapes (Fig. 2), or alternatively functions like ArcView ${ }^{\circledR}$ Q uery Builder can be used to select data with certain characteristics.

The data were plotted on a topographic map using conventional structural symbols, whereas orientationsand dip angles were colour-coded. For foliations and lineations, four maps with different colour codes were plotted (Figs 3-7). $\mathrm{H}$ aving attempted several different ways of displaying variations of dip/plungedirections on maps, wefound 


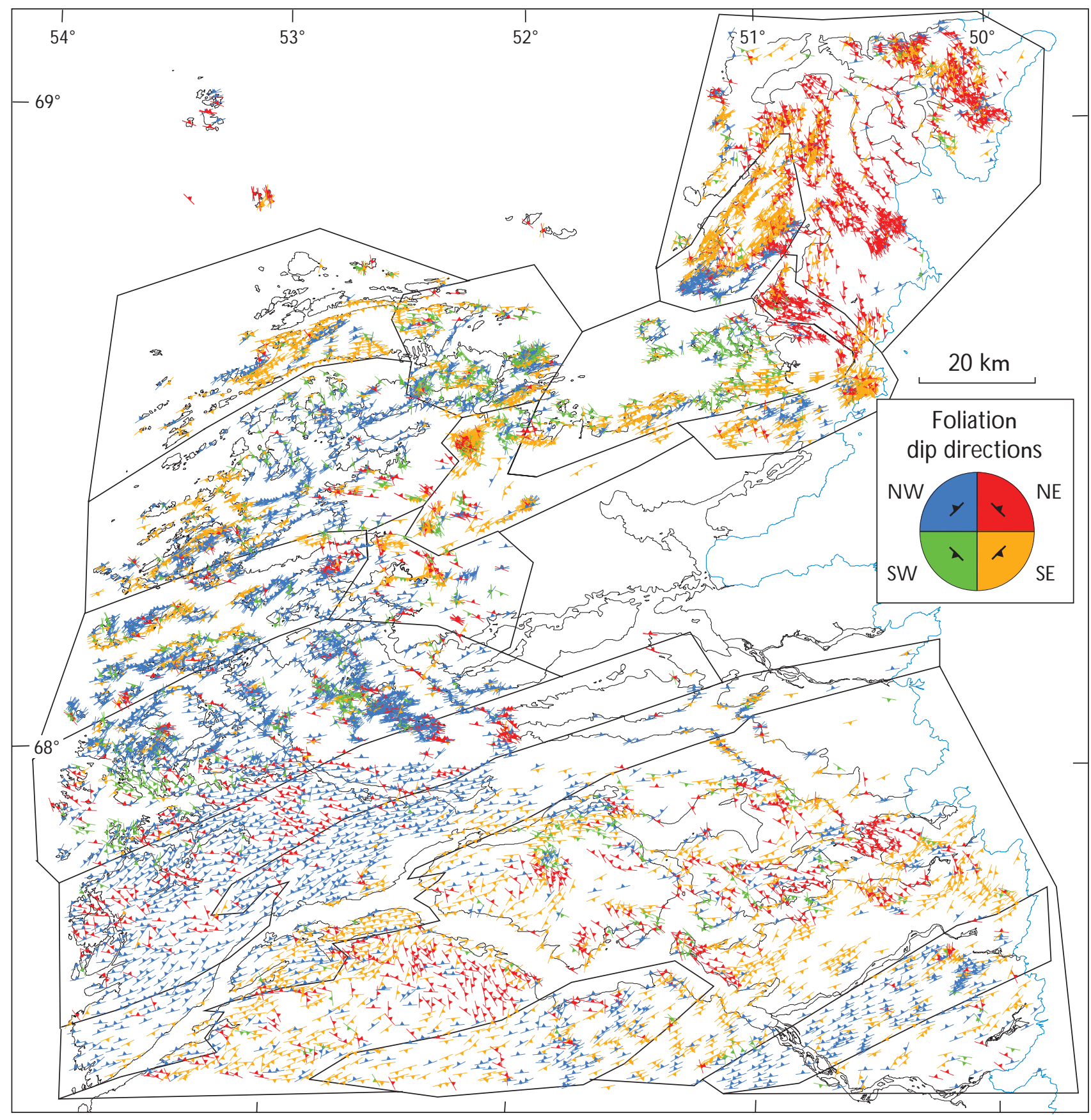

Fig. 3A. Foliation data, using four different colours to represent dip directions in the four quadrants of $0-90^{\circ}, 90-180^{\circ}, 180-270^{\circ}$ and $270-360^{\circ}$.

that the regional trends were best shown using a subdivision into colour-coded quadrants. T his gives a clear indication of variations on a regional scale and displays features that conventional plots of structural data would not have easily revealed. 0 ther features of the data could be highlighted with other methods of coding, or by plotting them on a different scale. The GIS program allows the user to change the coding criteria and colours with a lim- ited number of key strokes, and thus forms a powerful, user-friendly tool of analysis.

We plotted one map for each of the planar and linear datasets (Figs 3A, 5A), using differently coloured symbols for dip/plunge directions within each of four different quadrants: directions between $0-90^{\circ}$ (NE quadrant) are shown in red, $90-180^{\circ}$ (SE quadrant) in orange, 180$270^{\circ}$ (SW quadrant) in green, and $270-360^{\circ}$ (N W quad- 


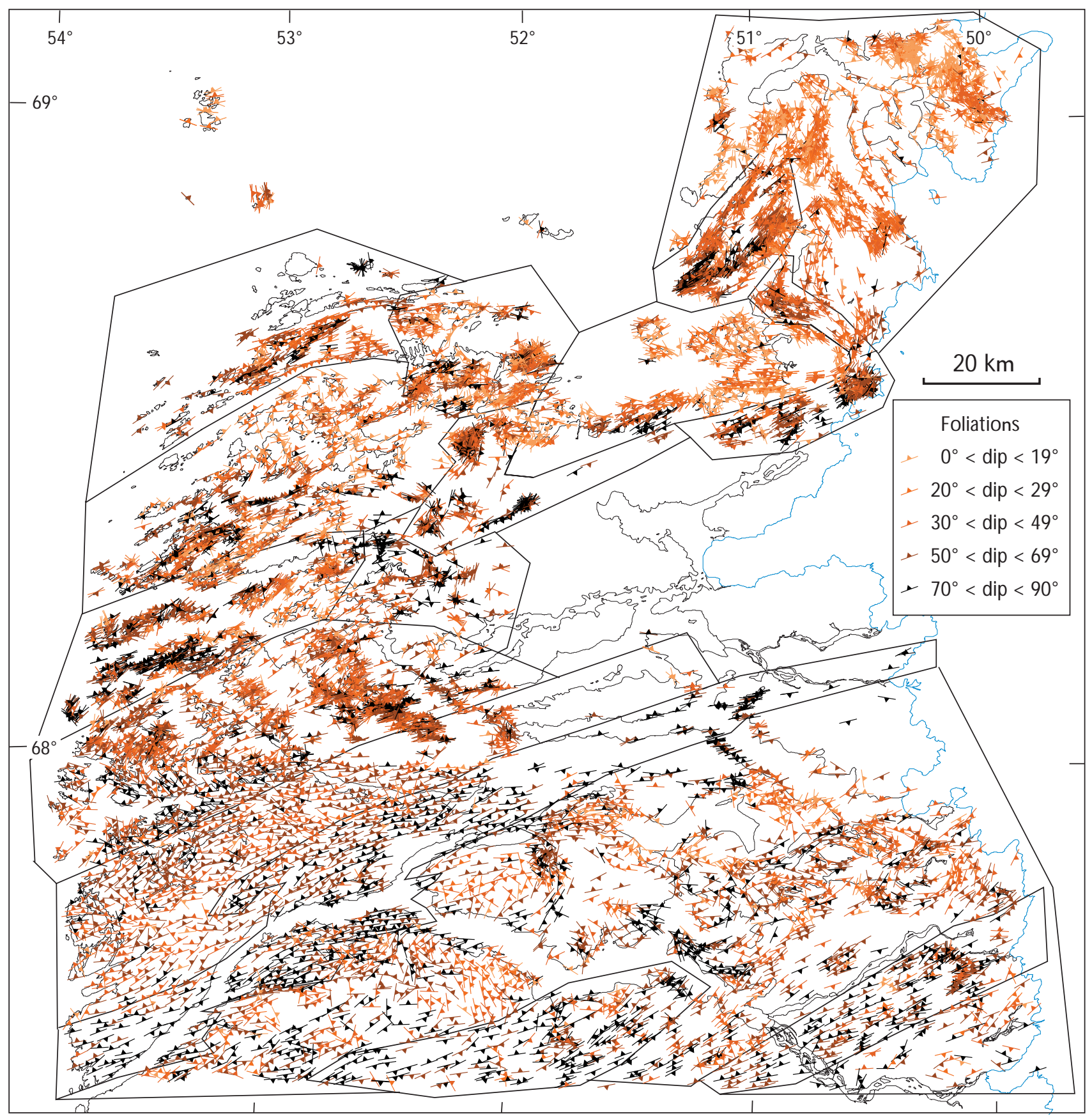

Fig. 3B. Foliation data, using colour intensity to reflect dip angle. D arker colours indicate steeper dip angles.

rant) in blue. We also plotted foliations, lineations and fold axes, respectively, in three maps where the colour intensity reflects the steepness of the dip/plunge (Figs 3B, $5 B, 7)$. Herethelight orange colour indicates shallow dips/ plunges, and darker brown to black colours indicate progressively steeper dips/plunges.

The data were also plotted in a third way by combining the two just described methods. The different colours weremaintained for the dip/plungedirections within each of the four quadrants, combined with colour intensity to display the variations in dip. Thefoliation data were split into two separateplots to show moredetail and avoid clutter: Fig. 4A showstheoverall EN E-W SW-trending structures (blueand orange), whereas Fig. $4 \mathrm{~B}$ contains the overall ESE-W N W-trending structures (red and green). A similar method was used for the lineations, however, on 


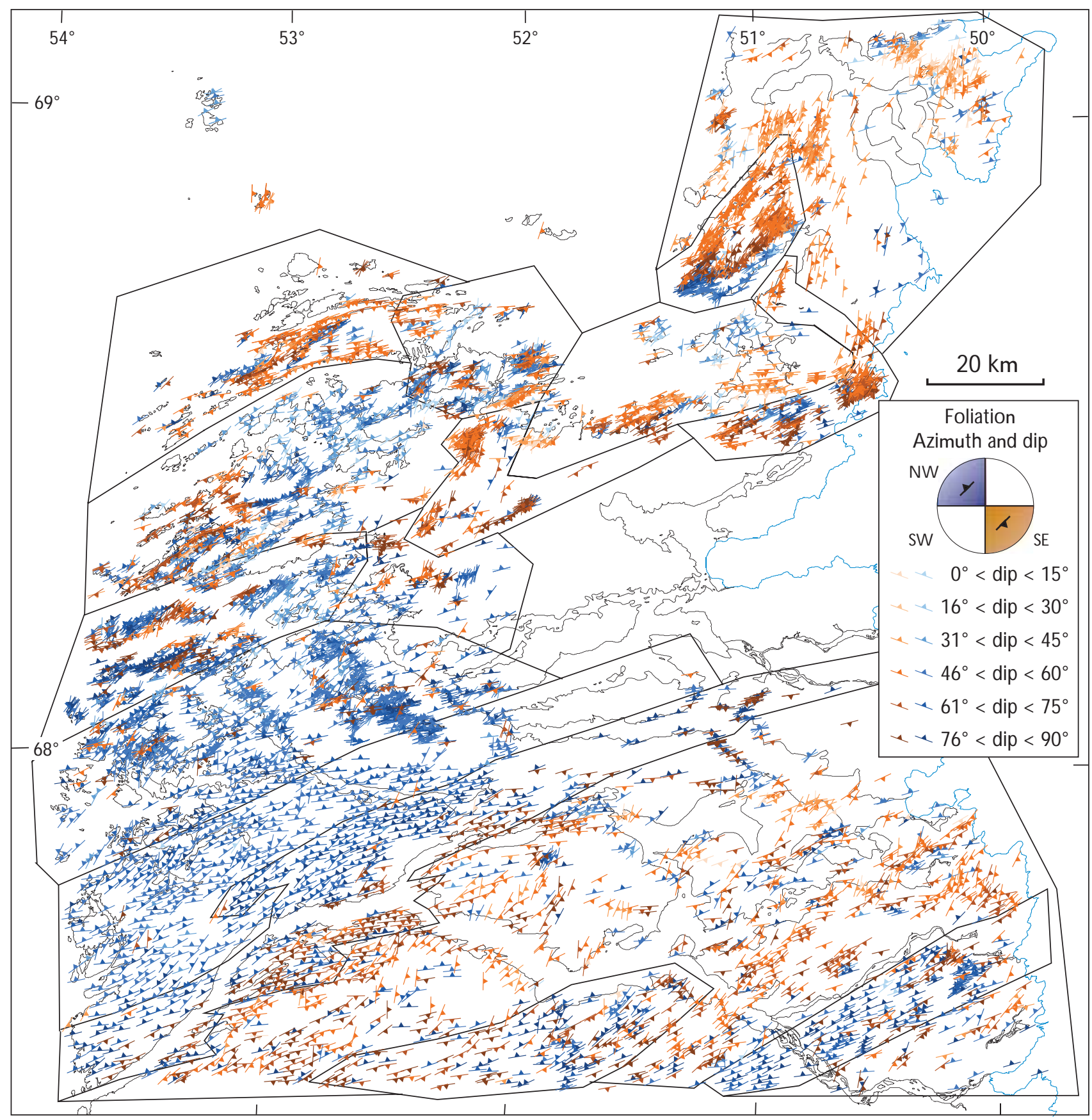

Fig. 4A. Foliation data, using blue and orange colours for N E-SW trends with N W and SE dips, respectively, combined with colour intensity to reflect dip angle. See Fig. 4B for N W-SE trends.

the scale of presentation many of the red and green lineations (EN E-W SW-trending) would overlap. Therefore, the green symbols were plotted separately (Fig. 6A), whereas the red symbols were included with the blue and orange ones (Fig. 6B); there are relatively few blue and orange symbols and therefore less cluttering.

There are significantly less measurements of fold axes than of other structural elements. Therefore we were not ableto usetheir orientations for analysis of regional trends, and the fold axes are only colour coded for plunge angle (Fig. 7).

In some areas the very high data density causes a saturation with the colour of the main orientation on the scale of presentation. Although themain trendscan still beseen, minor orientation components may be obscured. This problem can be overcome by zooming in on smaller areas 


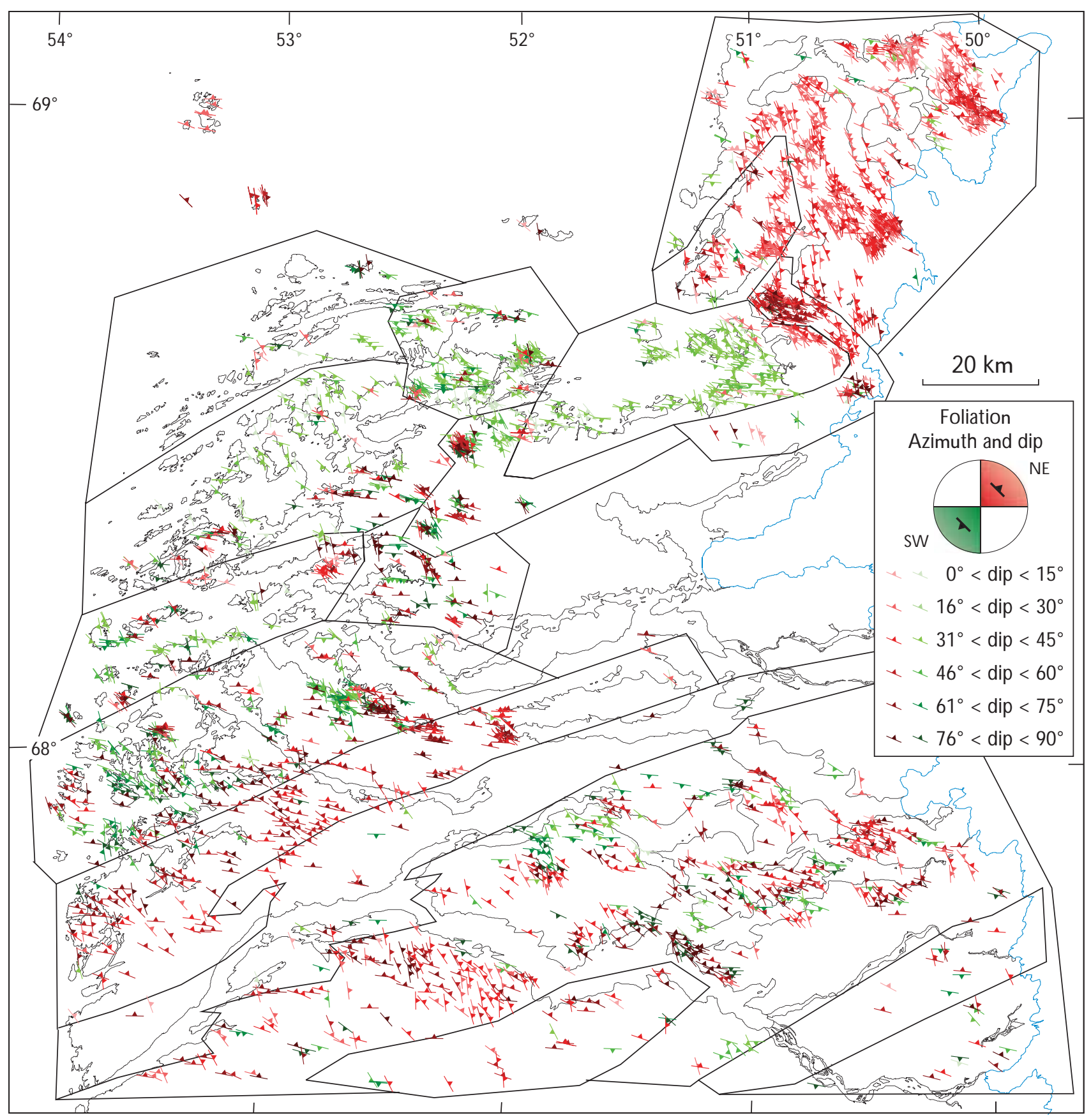

Fig. 4B. Foliation data, using red and green colours for NW-SE trends with N E and SW dips, respectively, combined with colour intensity to reflect dip angle. See Fig. 4 A for $\mathrm{NE}-\mathrm{SW}$ trends.

and printing on a different scale, revealing the full range of the data (e.g. M azur et al. 2006, this volume).

\section{Structural domains}

Apart from the general variations in structural style, it is apparent that there are well defined areas with distinct structural patterns. We therefore divided the whole study area into 16 structural domains (Fig. 2), within each of which the structural characteristics are largely consistent and more or less distinct from those of adjacent domains. this subdivision is exclusively based on visual evaluation of the plotted data. A more rigorous approach for the definition of domains would havebeen possible, for example the method by Vollmer (1990) based on eigenvalue cal- 


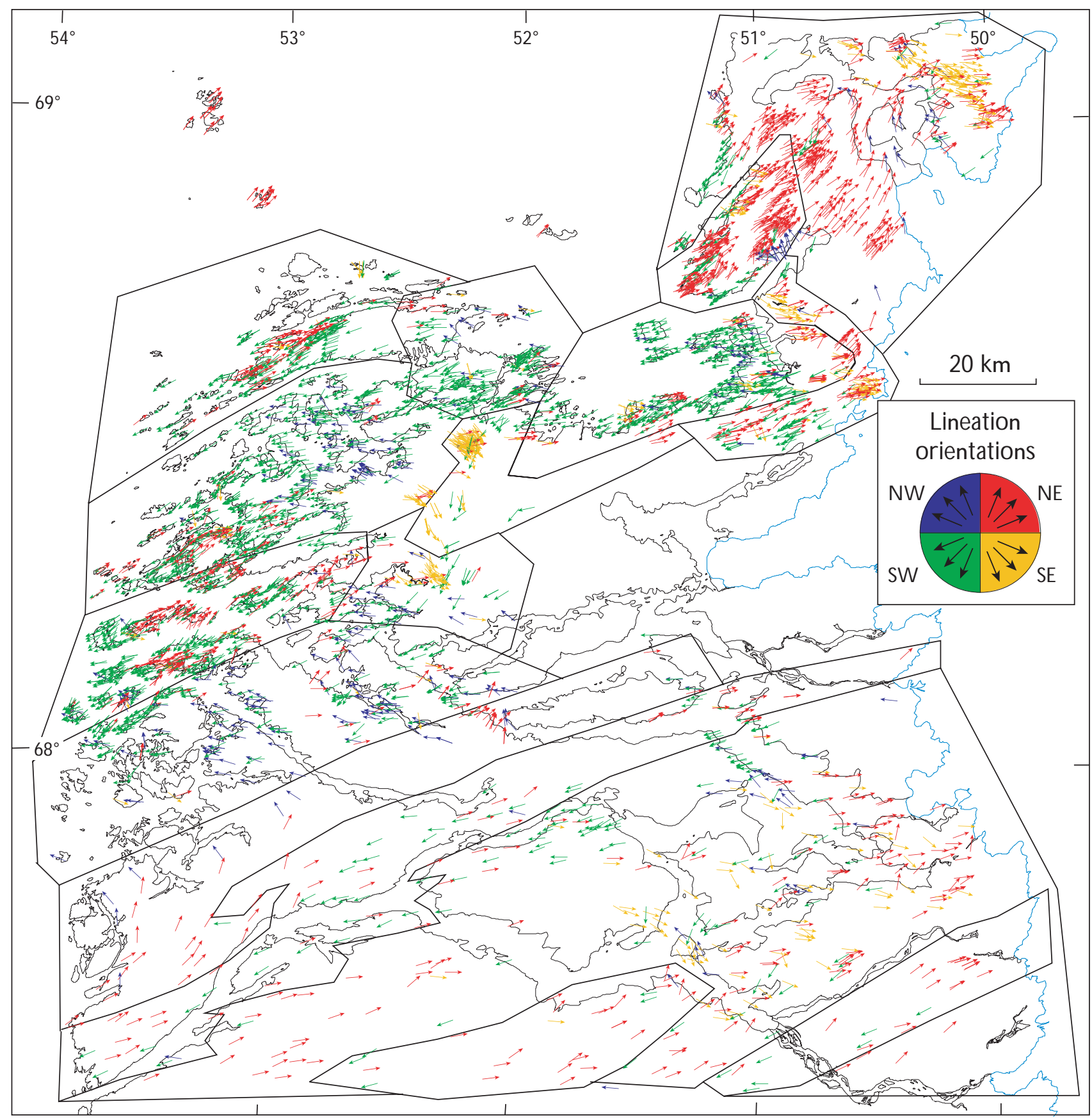

Fig. 5A. Lineation data, using four different colours to represent plunge directions in the four quadrants of $0-90^{\circ}, 90-180^{\circ}, 180-270^{\circ}$ and $270-$ $360^{\circ}$. See also Fig. 5B.

culations of data in small subsets, but is beyond the scope of the present study. The domains are presented schematically in Fig. 2, and their outlines are al so shown in Figs 3-8. The structural data for each of the domains were extracted and plotted as equal area, lower hemispherestereographic projections (Fig. 8). Foliations were plotted as poles to planes and contoured, and the orientation of the maximum density of data indicated in each plot. Great circles were calculated where visual inspection of the contoured data suggested that a great circle distribution exists. Calculations of great circle and fold axis orientations are based on the orientations of the three eigenvectors of the data. Thelarge number of datain the contoured plots resultsin an accentuation of the high concentrations, while smaller populations that define separatestructures are less visible. $\mathrm{H}$ owever, these are included in the calculations of 


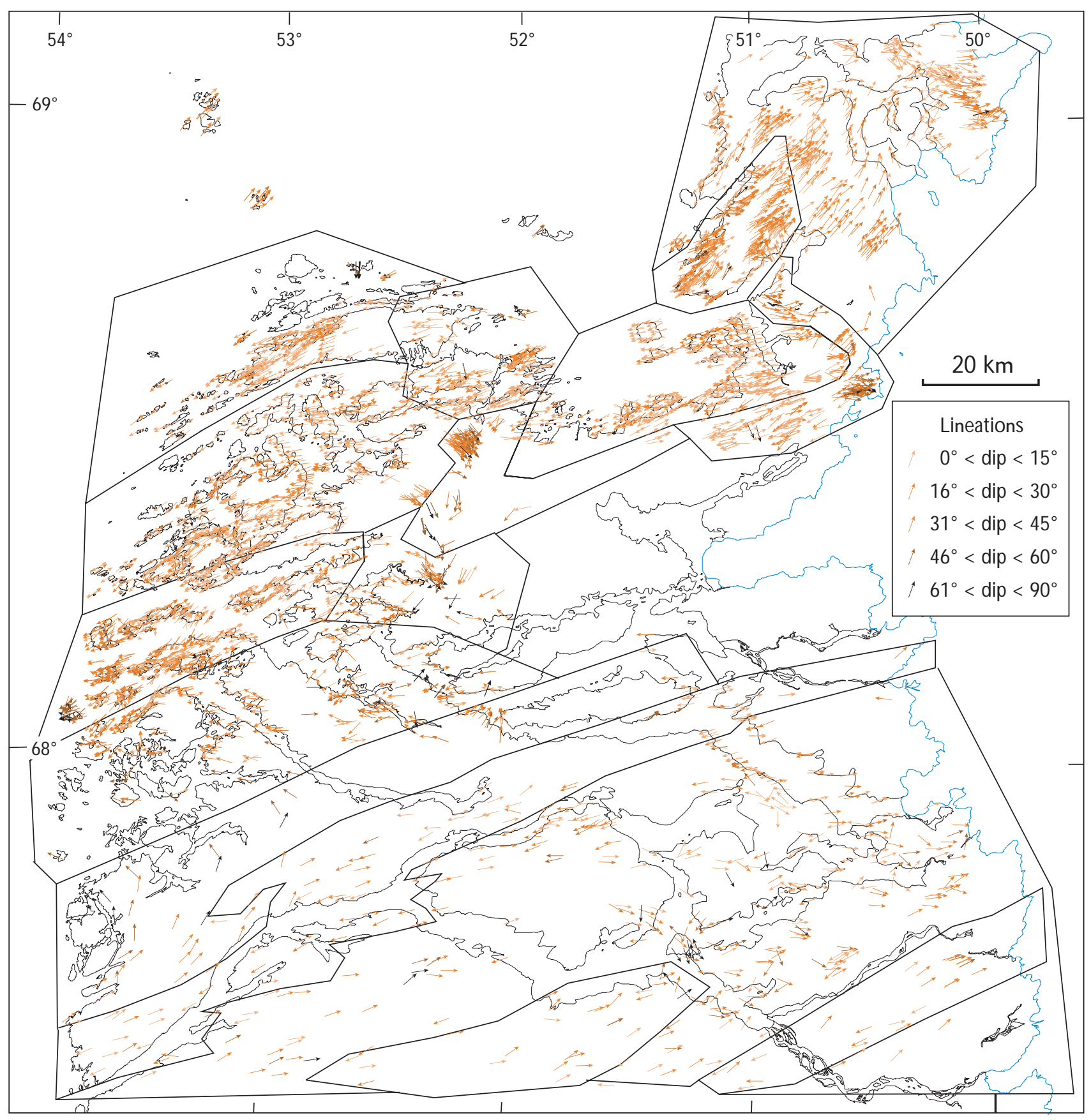

Fig. 5B. Lineation data, using colour intensity to reflect steepness of plunge. See al so Fig. 5A.

the great circles and fold axes, and therefore the calculated great circle may diverge from the one defined by the maximum orientations, as in domains 7, 9 and 14 (Fig. 8). Lineations were plotted and contoured, with indication of the orientation of the maximum concentration of data (Fig. 8B). Table 1 contains short descriptions of the characteristics of each domain regarding foliation, linear data and general geology.

\section{Results}

The main variations in the structural patterns within the study area are described in the following sections, using structural maps and stereographic projections (Figs 3-8). The structural variations are apparent at a first glance as clustering of data and variations in colours; they reflect the nature of the large-scal e tectonic evolution of the orogen, which is discussed in a final section. 


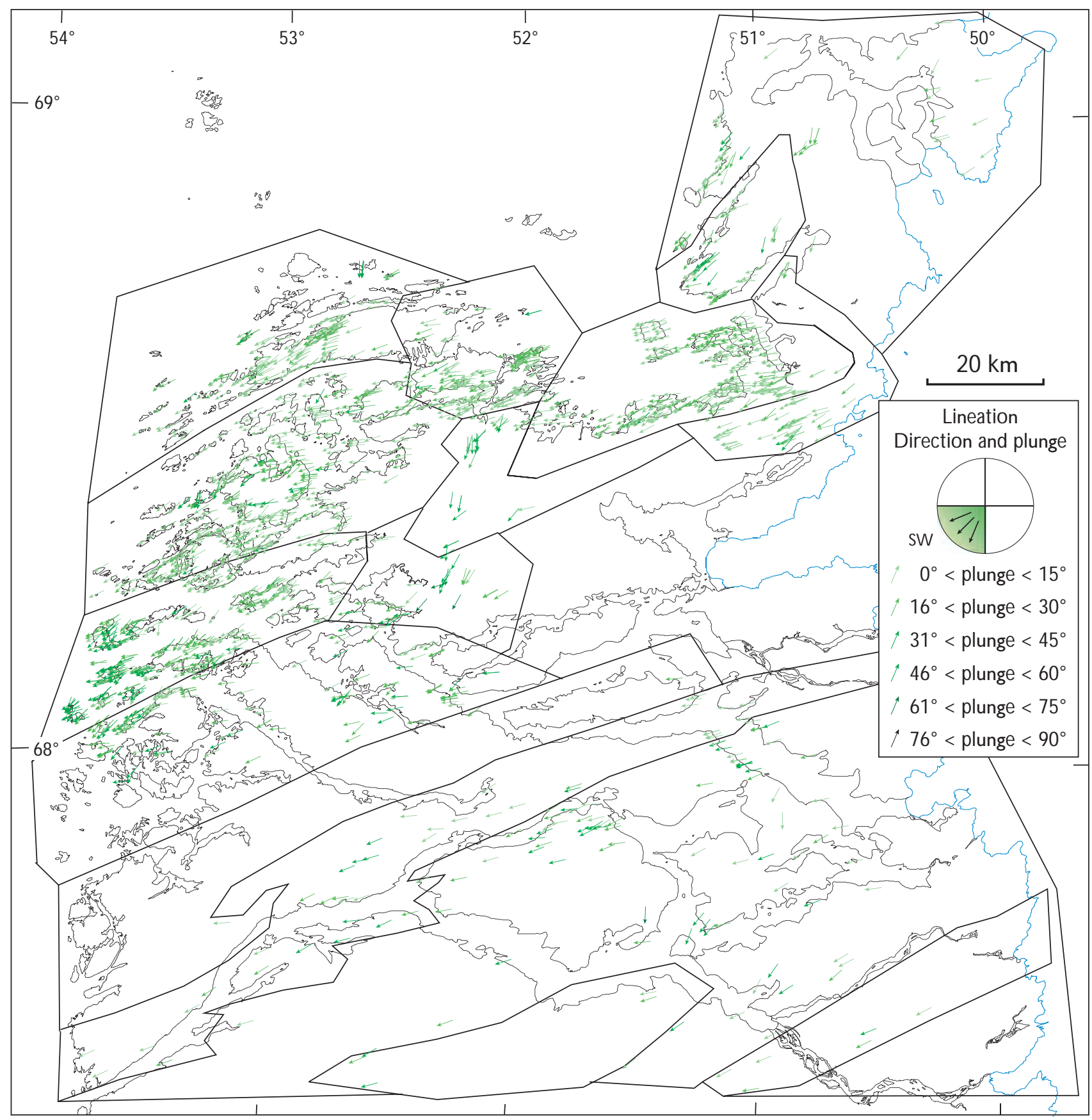

Fig. 6A. Lineation data, using green colour to represent SW directions and colour intensity to reflect steepness of plunge. See Fig. 6B for N W, NE and SE directions.

\section{Foliations}

0 verviews of the orientations of the planar fabrics are shown in Figs 3, 4. The predominant foliation trend is EN E-W SW, shown in orange and blue colours. Linear beltsin this direction, dominated by steeply dipping foliations, alternate with broader regions characterised by strongly variable orientations. These belts and regions with different structural characteristics have previously been referred to as steep belts and flat belts, respectively ( $M$ arker et al. 1995). T he distinct alternation between such distinct linear belts and folded regions diminishes towards thenorth, and the predominant general EN E-W SW trend becomes progressively weaker, as reflected by the increase of red- and green-coloured symbols. This is apparent especially in the north-eastern corner of the study region, where the foliations are dominated by NE dip directions 


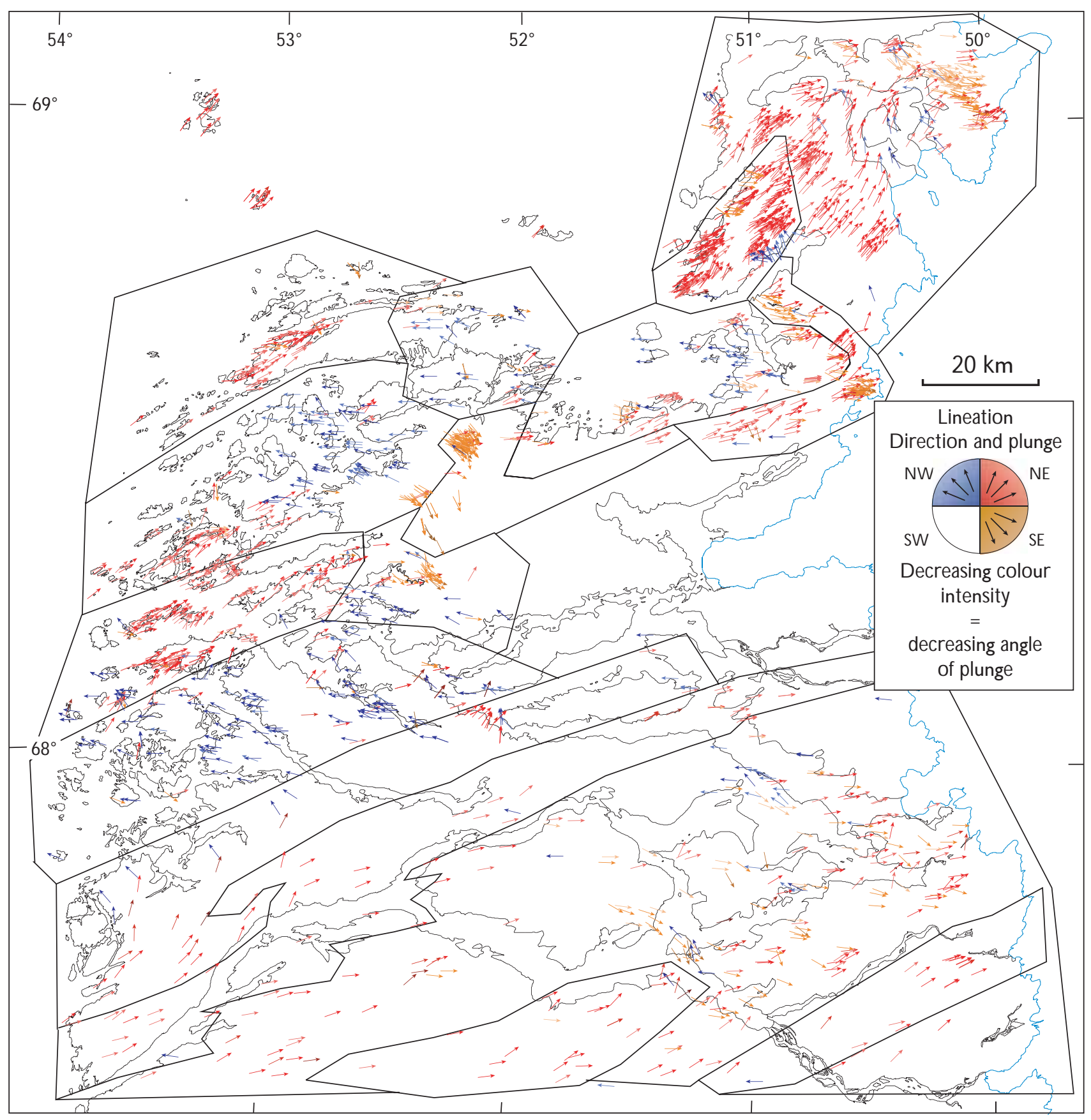

Fig. 6B. Lineation data, using blue, red and orange colours for NW, NE and SE orientations, respectively, combined with colour intensity to reflect steepness of plunge. See Fig. 6 A for SW directions.

shown in red. Coupled with this progressive change towards the north there is an overall decrease in the dip angle, as expressed by an increasing amount of light orange-coloured symbols.

In the south, thetwo main linear belts, the N ordre Isortoq steep belt in domain 1 and the N ordre Strømfjord shear zone in domain 4 , are characterised by a near-uniform ENE-W SW-trending foliation, a marked absence of N W-SE-trending foliations, and steep dip angles. A third linear belt in thenorth, the $N$ aternaq belt in domains 12 and 13 and the northern part of domain 7, is discontinuous and less well defined. Smaller, discontinuous shear zones also occur in the N N 0 e.g. in domains 10 and 15; these are indicated by strong clustering and alignment of symbols of the same colour, but not necessarily by steep dips. Dip directions of the overall EN E-W SW -trending 


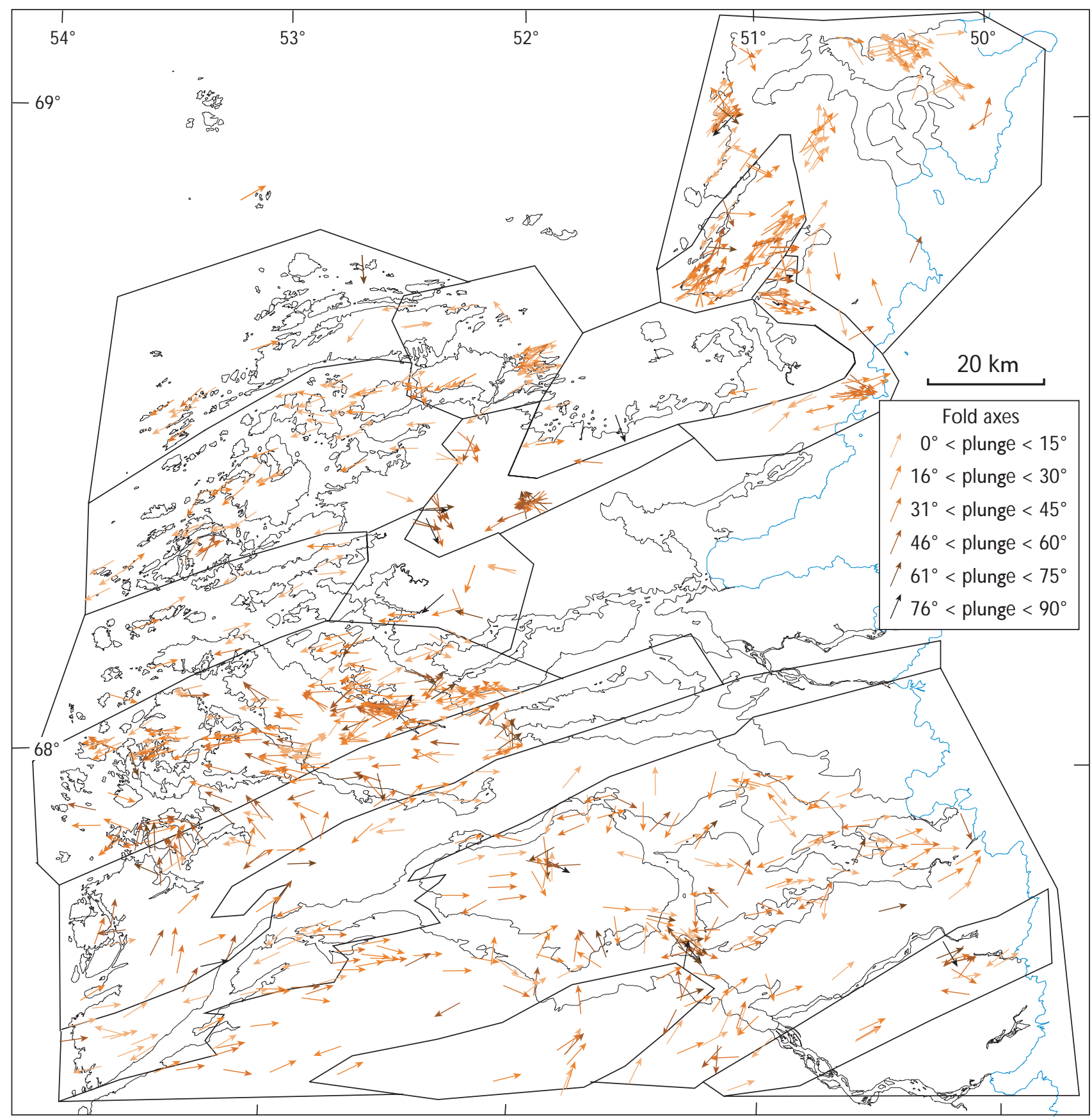

Fig. 7. Fold axis data, using colour intensity to reflect steepness of plunge.

structures (in blue and orange colours, Fig. 3A) show a clear regional pattern of alternating N W and SE dip directions. In the south, switches in dip directions are associated with the two main linear belts such that the intervening area, which forms a large anticlinorium (van $\mathrm{G}$ ool et al. 2002), is characterised by predominant SSE dips (in orange), while N N W dips (in blue) prevail to the north and south. N W -SE-trending foliations are predominant in two distinct areas in the north-east: one in the extreme north-eastern corner with predominating N E-dipping foliations (in red), and another around Sydostbugten, characterised by SW -dipping foliations (in green). Farther south only two areasof uniform dip directionsarerecognised, one around Attu with predominant SW dips (in green), and another formingabelt north of theN ordreStrømfjord shear zone, which has uniform N W dips (in blue). 


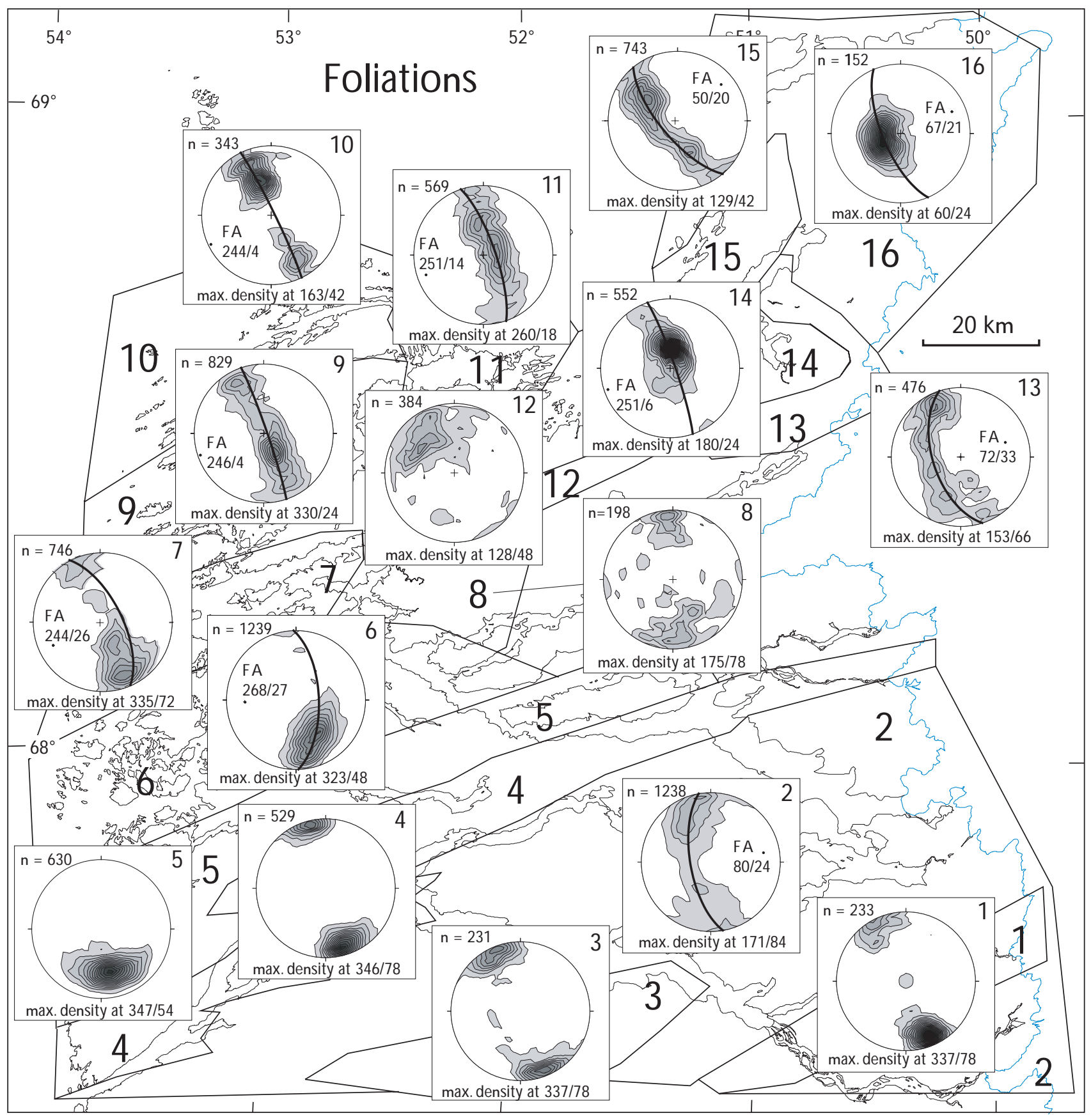

Fig. 8A. Characterisation of structural domains from Fig. 2 with stereographic projections of foliations within each domain. Poles to foliations plotted on lower hemisphere, equal angle nets and contoured at 1, 2, 3, etc. times random distribution. The number of data points (n) and orientation of maximum density are indicated for each plot. FA, calculated fold axis. 


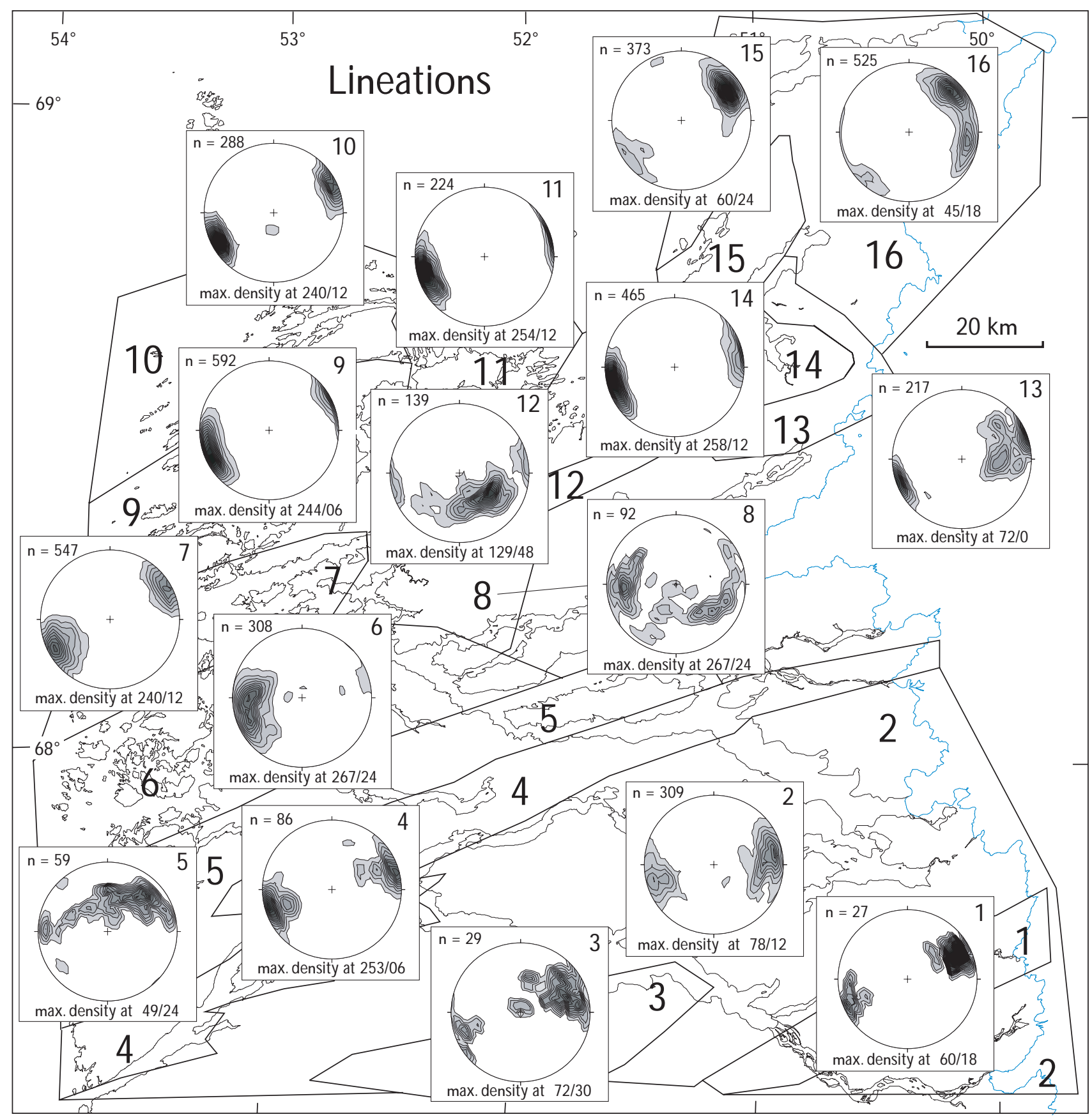

Fig. 8B. Characterisation of structural domains from Fig. 2 with stereographic projections of lineations within each domain. D ata plotted on lower hemisphere, equal angle nets and contoured at 1, 2, 3, etc. times random distribution. The number of data points ( $\mathbf{n}$ ) and orientation of maximum density are indicated for each plot. 
Table 1. Summary of characteristic features of the structural do mains

\begin{tabular}{l}
\hline Domain Foliation \\
\hline 1 Steep N -dipping foliation with \\
consistent orientation. A sharp \\
transition to S-dipping foliations at \\
the northern bo undary of the belt. \\
2 Foliation curved along shallowly \\
EN E-plunging folds on a scale of tens \\
of kilometres. Dips variable, SE dips \\
predominating over N E and less \\
common SW dips.
\end{tabular}

3 Steep foliation. Both northerly and so utherly dips. Few folds on scales of $0.5-1 \mathrm{~km}$.

\section{Lineation}

Consistent, predominant shallow EN E plunge.

Variable lineations, with predominant shallow EN E plunges, parallel with fold axes. Shallow, SE-plunging lineations in a c. $10 \mathrm{~km}$ wide zone south of the N SSZ.

Lineations mainly shallowly EN E-plunging. Some variation in fold hinges, especially near the eastern domain boundary.

Subhorizontal lineations, the NSSZ. Interleaved

4 Steep foliations with consistent orientations, slightly oblique to the trend of the linear belt. $N$ ortherly dips predominate. $N$ ear the so uthern areas. boundary a sharp transition to SSE-dipping foliations.

5 Gradual northward transition from steep dips close to the N SSZ to shallower N N W dips. The foliation locally curves into the shear zone. NE dips are mixed with the dominant N N W dips in most of the area. The plentiful data points on the stereonet (Fig. 8A) obscure orientations (mainly $\mathrm{N}$ E-dipping) away from the maximum.

6 Intensely folded region with 5-10 km Mixed orientations with a large folds, mainly W-plunging. $\mathrm{N}$ ortherly and westerly dips predominate in contrast to domain 5.

Variable strike. N N W dips less 7 predominant than in domain 5. Folding. Dips mainly moderate, but steep in the south-west. Fig. $8 \mathrm{~A}$ displays a girdle over shallow, W SW-plunging fold structures. majo rity W SW -plunging in contrast with surrounding

Progressive change from shallow EN E plunges near the N SSZ towards steep $\mathrm{NE}$ and $\mathrm{N}$ plunges in the north-west. cluster of shallowly SE-plunging lineations. In the west progressive change in orientation continues from domain 5. More variable orientations in the east.

Rather consistent EN Etrending lineations. EN E plunges in the east become shallower and mixed with W SW -plunging domains in the west, followed by A calculated great circle is discordant moderate to steep W SW to the measured maxima, which align plunges at the coast. Locally on a steeper great circle.

steep lineations in fold cores.

8 Foliations outline the large fold structure visible on Fig. 1. Southerly dips predominate in the northern part (green and orange/brown, Fig. 3A). A zone with N W dips (blue) runs through the do main centre. Mixed dip directions in the so uth. $D$ ips moderate to steep. Irregular stereonet pattern (Fig. 8A), with remnants of a great circle distribution similar to that in do mains 6 and 7.
Steep SW - and SE-plunging lineations around a large central fold core. Mainly $\mathrm{E}-\mathrm{W}$-trending lineations in the west in transition to domain 7.Variable lineations in the east. Two maxima of shallow W plunges and steeper SE plunges (Fig. 8B), the latter possibly with a small circle distribution.

\section{Geology \\ Synopsis}

N ordre Isortoq steep High-strain strike-slip zone constrained by belt (shear zone), metasedimentary rocks.

predominant sinistral

shear. Mainly paragneiss.
Northern CNO flat belt of interleaved Archaean orthogneisses and Proterozoic ortho - and paragneisses.

Steep belt within the northern CNO flat belt; tightly interleaved ortho- and paragneisses.

ortho- and paragneisses.

Anticlinorium between two shear zones. Lineation constant in spite of intense folding. 0 nly one zone where lineations plunge SE, locally steeply.

Steep zone with tight folds within the larger domain 2 with large fold structures. Steep zone discontinuo us to the east, and concentrated in an area do minated by two metasedimentary belts.

Sinistral strike slip zone5 km wide 0 bliquity of foliation fits with sinistral shear.

Archaean orthogneisses and horizons of supracrustal amphibolite.
Region with shallow, N-dipping structures.
Archaean indentor, ortho- and paragneiss as in domain 5. Large fold structures.
$O$ verall $W$ - and W SW -plunging folds Two sets of lineations, one variable, the other consistently W SW -plunging, parallel with fold axis.
Archaean orthogneisses Predominantly straight and steep foliations and metasedimentary with EN E trends, but variable dip rocks define a poorly directions, and consistently shallow sampled linear zone at lineations. Misalignment of foliation girdle the northern boundary and calculated great circle (Fig. 8A) of the indentor block indicates complex fold pattern: along-strike of Piazo lo et al. (2004). variation of lineations (and presumably fold A few kilometre-sized axes) and local folds with steep axes disturb fold structures. the stereographic plot. N on-consistent dip directions and dips in the northern linear zone suggest intense folding.

Orthogneisses Mixed structural patterns including interleaved with supra- EN E-trending fold limbs and fold interfecrustal amphibolite. rence patterns. The core of the large fold A fold interference pattern occurs south of the main fold at the western end of the with the steep lineations is located along the southern extension of a N N E-trending belt of steep lineations on the western $\mathrm{N}$ aternaq belt. 
Table 1 (continued)

\begin{tabular}{|c|c|c|c|}
\hline Foliation & Lineation & Geology & Synopsis \\
\hline $\begin{array}{l}9 \text { C onsistent EN E trend with both } \\
\text { N N W and SSE dip directions. Large } \\
\text { fold structures in the east. Steep dips, } \\
\text { shallower towards north. G reat circle } \\
\text { distribution with shallowly N N W - } \\
\text { dipping and subo rdinate steep, } \\
\text { SSW -dipping flanks tentatively } \\
\text { interpreted as due to asymmetric } \\
\text { S-vergent folds (Fig. 8A). }\end{array}$ & $\begin{array}{l}\text { Predominant subhorizontal } \\
\text { EN E-W SW-trending lineations, } \\
\text { gradually changing to E-W in the } \\
\text { east, where large-scale folds } \\
\text { occur. Very strong preferred } \\
\text { EN E-W SW subhorizontal } \\
\text { orientation, with a tail towards } \\
\text { E-W trends displayed on Fig. 8B. }\end{array}$ & $\begin{array}{l}\text { Region around Kangaat- } \\
\text { siaq with metasedimen- } \\
\text { tary rocks, amphibolite } \\
\text { and granite within the } \\
\text { regional grey gneiss. }\end{array}$ & $\begin{array}{l}\text { Transition from predominant } \\
\text { steep, northerly dips in the CN } 0 \\
\text { to shallower, variable dips and } \\
\text { large fold structures in the north. } \\
\text { From east to west a large swing } \\
\text { from EN E-SSW to E-W trends. } \\
\text { Lineations uniform also in the area } \\
\text { of large folds. }\end{array}$ \\
\hline
\end{tabular}

10 Mainly steep $S$ dips with consistent trend.As in domain 9, EN E-W SW trending foliation in the west swings towards $E-W$ in the east.At the so uthern boundary a linear belt with moderate S dip. Partial great circle distribution; no dip directions within the NE quadrant (Fig. 8A).

11 Foliations outline aW -plunging antiform c. $10 \mathrm{~km}$ large The norther Shallow plunges of lineations, part of its northern limb appears overturned towards N. G reat circle distribution with predominant shallow to moderate dips on stereonet (Fig. 8A).

Consistent EN E-W SW-trending subhorizontal lineations, with indistinct domains of respectively easterly and westerly plunges. Strong point maximum on stereonet with shallow W SW plunges (Fig. 8B).

Shallow plunges of lineations, mainly towards W. Subordinate $\mathrm{NW}$ plunges on northern fold limb. Fig. 8B shows strong point maximum parallel with calculated fold axis.

Straight zone of predominant orthogneisses aro und $A$ asiaat, bounded to the south by a high-strain zone.

Ikamiut supracrustal on its so uthern limb. N orthern limb poorly exposed and undersamp-
Very consistent foliation trends, the northernmost widespread steeply dipping foliations, and very persistent lineations.

12 Foliations outline a fold with a folded, overall moderately SE-dipping western main limb.The high-strain so uthern limb dips steeply S. Large spread on stereonet (Fig. 8A).

Moderately SE-plunging lineations on the western limb, with isolated SSW plunges in hinge zone. Very few measurements on the southern limb, with shallow W SW plunges. Data consistent with a shallowly rocks. Lar ge antiform with $W$-plunging antiform becoming $1 \mathrm{~km}$-scale parasitic folds progressively tighter westward led. (but not easily traced into domain 10).

W estern $\mathrm{N}$ aternaq belt. Steep paragneisses folded
on $20 \mathrm{~km}$-scale. Mainly data from isoclinal fold on western limb; less from straight so uthern limb.

W ester $n$ limb of $\mathrm{N}$ aternaq supracrustal belt, forming a distinct zone, apparently transecting the overall EN E-trending fabric, and with uncommon SE-plunging lineations and fold axes.

Lineations shallow and ENE- or

13 Eastern continuation of steep, high-strain southern limb of fold from W SW-plunging on the southern domain 12 and large E-plunging antiform. NW dips more common in the north, dips shallower near hinge. The northern limb has moderate to steep N E dip. Fig. 8A shows a well-defined great circle and $\mathrm{N}$ E-plunging calculated fold axis.

14 Irregular foliation in the core of the eastern $\mathrm{N}$ aternaq fold, forming an E-W -trending whaleback structure. Fig. 8A shows a point maximum and partial girdle which do not fit the calculated great circle (see the main text).

15 Foliations define a large, open $\mathrm{N}$ E-trending synform with steepest orientations in the core, bo unded by straight belts. An antiform occurs in the so uth-east, with its southern lim in domain 13. A well-defined great circle on Fig. 8A indicates cylindrical, $\mathrm{N}$ E-plunging folds. limb.Variable plunges on the eastern limb between N E and ESE.The latter orientation most common in hinge areas. Fig. 8B clearly shows these three separate populations.

Steeply dipping, straight gneisses in eastern $\mathrm{N}$ aternaq belt. A large E-plunging antiform at the eastern end, and a north-eastern fold limb with only minor metasedimentary rocks.

Consistent lineation trend in antiform, but opposite plunge directions on the limbs. Steeper lineations in the fold hinge.

Predominant subhorizontal W SW plunges, except EN E plunges at the eastern domain margin along the eastern limb of the map-scale fold. Fig. 8B shows a single strong point maximum.

Predominantly orthogneiss, cut by flat-lying shear zones.

Very consistent lineation trends, also through the antiform in the east. Direction of plunge flips over in the east, perhaps indicating two generations of lineations.

Strong predominance of EN E-plunging lineations along the synform axis. Consistent SE plunges so uth-east of the shear zone. C onsistent moderate N W plunge in the antiform near head of fjord. Fig. 8B shows a fairly well defined point maximum close to the calculated fold axis.

Predominant shallow, N E-plunging lineations and a small po pulation of slightly steeper, E-plunging lineations in the north-eastern domain corner. The lineations swing, following the folds.
Synform with strongly migmatitic paragneiss and a core of migmatitic orthogneiss. High-strain zones to the north-west and south-east.
The so uth-eastern limb of the synform, overturned to the north-west and becoming very tight towards north-east. Distinctly different lineations in the underlying, folded shear zone.
16 The foliation defines large, open, $\mathrm{N}$ E-plunging folds besides a large antiform surrounding the synform of domain 15.The stereonet data (Fig. $8 \mathrm{~A}$ ) display a point maximum with a partial great circle distribution.
Archaean orthogneiss with thin sheets of pelitic rocks and supracrustal $\begin{array}{ll}\text { very weakly foliated } & \text { side of the synform in do main } 15 \\ \text { porphyritic granodiorite. } & \text { does not continue in do main } 16 .\end{array}$ different from elsewhere in N N O.

The N E-dipping orientations and open folds are significantly 
The stereographic projections of the foliations clearly reflect two trends (Fig. 8A). The plots from the southern part of the study area define alternating point maxima and great circle distributions, reflecting, respectively, the linear belts and the fold-dominated regions. In contrast, in most of the N NO the plots mainly display (partial) great circle distributions or otherwise irregular patterns, indicating the lack of extensive linear belts in the north. Furthermore, the stereographic projections reflect the northward decrease in dip angle: in the $\mathrm{CNO}$ the point maxima indicate dip angles around $80^{\circ}$, whereas the N N 0 is characterised by point maxima indicating dip angles in the range $20-40^{\circ}$.

\section{Lineations}

0 verviews of the linear fabrics are shown in Figs 5,6 . T he highly uneven data density in the lineation maps (Fig. 5A, $B$ ) reflects that the southern and northern parts of these maps have been compiled from different sources, i.e. published maps in the south and complete field datasets in the north. N evertheless, it is apparent that the dominant trend is EN E-W SW, as indicated by the predominant red and green colours (Fig. 5). 0 utside the linear belts, gradual changes in the lineation trends on a scale of 10-50 $\mathrm{km}$ or more are seen, for example between Attu and $\mathrm{N}$ ordre Strømfjord, at western U ssuit, and in the north-east of the study area. Several smaller areas are dominated by E-W trends, for example east of Attu, south-east of Sydostbugten, and south of Jakobshavn Isfjord.

M ost lineations plunge $0-30^{\circ}$, with markedly steeper plunges in regions of map-scale fold interference structures and fold hinges. This is prominent west of Ataneq, north-west of Attu, and in the eastern part of domain 13. These regions are also characterised by orientations that diverge from the general ENE-W SW trend.

The structural maps (Fig. 6) stereographic projections (Fig. 8B) clearly show that W SW -plunging lineations predominate in most of the NNO (north of the Nordre Strømfjord shear zone) except for small clusters of NEplunging lineations and the area east and north-east of Sydostbugten, wherethe plungeis towards EN E (domains 13, 15 and 16); there is a sharp break between these two plunge directions east of Sydostbugten. The same pattern is shown by the fold axes calculated from the great circle girdles of the foliations (Fig. 8A). South of the N ordre Strømfjord shear zone (in the C N O), the point maxima of the lineations and calculated fold axes consistently indicate shallow EN E plunges.

\section{Fold axes}

0 rientations of fold axes are shown on Fig. 7. The symbols are colour-coded for plunge angle in order to facilitate comparison with the lineation data. The orientations of the fold axes mimic the general characteristics of the lineations, being generally subparallel with thelatter. Their distribution in clusters reflects a higher density of measurements in areas of map-scale fold hinges, where outcrop-scale folds are more common.

\section{Tectonic implications}

The structural data presented in this paper show that the tectonic style changes significantly across the central and northern parts of the $\mathrm{N}$ agssugtogidian orogen. W hile the $\mathrm{CN} O$ is dominated by steep, linear and continuous belts separated by well-defined areas of large-scale folding, the NNO does not contain such continuous, linear belts, whereas 20-80 km-scale folds are abundant. The main change in tectonic style occurs across the N ordre Strømfjord shear zone. More specifically, the southern part of thestudy area (the C N $\mathrm{O}$ and the N ordre Strømfjord shear zone) is dominated by alternating linear belts and folded regions. Thecorresponding structural domains follow the main strike of the linear belts and are continuous from the coast to the I nland I ce. The linear belts themsel ves are dominated by sinistral strike-slip deformation. In contrast, the domains in the N N $\mathrm{O}$ are generally less elongate and reflect the lack of linear belts of similar dimensions as in the CN O. Small high-strain zones are observed locally, e.g. along the northern and southern margins of domain 15 and with several examples in domains 7, 9 and 10. Shear sense indicators are rare and inconsistent in the $\mathrm{N} \mathrm{N} \mathrm{O}$, and the overall deformation in this region seems to be predominantly coaxial (Piazolo et al. 2004; M azur et al. 2006, this volume). The change in tectonic style is interpreted to be a result of (a) differences in localisation of strain as high-strain, steep belts, (b) different deformation kinematics (strike-slip wrench tectonics in the south, coaxial deformation in the north), and (c) variations in theintensity of deformation. We consider that the overall Palaeoproterozoic strain is significantly lower in the N N 0 than in the CN O. The N N O commonly preserves shallow dips, which presumably predominated after theoriginal phase of thrusting. Besides, the two latest deformation phases, which are responsible for the steep foliation in the C N 0 , are less intense in the N N 0 (van Gool et al. 2002; Piazolo et al. 2004; M azur et al. 2006, this volume). These observations may account for the previously 
outlined differences in the mode of strain localisation. The data presented here furthermore show that the change in style is rather abrupt across the N ordre Strømfjord shear zone, and thus support the interpretation by Sørensen (1983) and Sørensen et al. (2006, this volume) that this structure is of crustal scale and has a significant offset - a notion that has previously been questioned by $\mathrm{H}$ anmer et al. (1997).

It is well established in the literature that the structural pattern of the C $\mathrm{N} O$ isfully attributed to $\mathrm{N}$ agssugtogidian deformation (van Gool et al. 2002). I n contrast, theN N 0 is currently interpreted as having only in part been affected by Palaeoproterozoic deformation, and the N agssugtoqidian strain is furthermore partitioned into smaller re gions (Piazolo et al. 2004; M azur et al. 2006, this volume). A significant part of the deformation in the N N 0 thus seems to be of Archaean age, and its overall structural style defined by interference between Archaean and Palaeoproterozoic structures. Therefore, like $M$ azur et al. (2006, this volume) we suggest that the change in tectonic style from south to north reflects partitioning of $\mathrm{N}$ agssugtogidian strain. This is clearly illustrated by the smaller and less elongate structural domains in the $\mathrm{N} \mathrm{N} \mathrm{O}$, and by the significant change of the general trend of both foliations and lineations towards the north-eastern corner of the study area, where we consider that the influence of thePalaeoproterozoic deformation diminishes rapidly. This interpretation is supported by the relatively low metamorphic temperatures recorded by $\mathrm{H}$ ollis et al. (2006, this volume) in some parts of the N N O.

It is beyond the scope of this contribution to explore the details of the structural domains that we have outlined. However, three other contributions in the present volume of G eological Survey of D enmark and Greenland Bulletin deal with the specific nature of some of these domains. Sørensen et al. (2006, this volume) investigate the character of the N ordre Strømfjord shear zone and adjacent areas in domains 4 and 5, M azur et al. (2006, this volume) focus on the partioning of structures within domains 6, 7 and 8, and Hollis et al. (2006, this volume) describe structures within domains 11 and 15.

\section{Conclusions}

The application of a GIS computer program enables us to visualise large amounts of structural data in a variety of ways. Thus, we can rapidly obtain an overview of large datasets that are otherwise difficult to manage, and delineate areas with consistent tectonic trends. Although the methods applied here de not reveal features that are not present in the original geological maps, they can substantially facilitate the detection and description of structural trends and variations. In addition, stereographic plots of each of the domains can quickly be produced and analysed. In the present case, the methods greatly helped to subdivide the central and northern N agssugtogidian orogen into distinct structural domains with specific individual characters.

The investigation of the large-scale structural trendsin the central and northern N agssugtogidian orogen revealed distinct changes in the tectonic style from south to north. In the core of the orogen, theEN E-striking N ordre Strømfjord shear zone from the coast to the Inland Ice forms the most prominent feature. The tectonic character of the orogen changes across this structure from predominantly EN E-tending, steep fabrics in the south to large fold patterns and generally flat structures in the north, with a marked decrease in the main dip angle from $c .80^{\circ}$ south of the shear zone, to $c .20-40^{\circ}$ in the north. In addition, a significant decrease in the intensity of deformation is apparent, coupled with a decreasing proportion of the strain localised in linear belts. We interpret these patterns as reflecting a general northward decrease in the Palaeoproterozoic tectonic overprint on Archaean structures, as well as strain partitioning in smaller regions. H ence, some of the structural domains in the N N $\mathrm{O}$ are largely unaffected by pervasive Palaeoproterozoic deformation.

\section{Acknowledgements}

Reviews by John Grocott and Ken M cC affrey are gratefully acknowledged.

\section{References}

Bonham-Carter, G .F., Agterberg, F.P. \& Wright. D.F. 1990: W eights of evidence modelling: a new approach to mapping mineral potential. Geological Survey of Canada Paper 89, 171-183.

Books, C.J. 2000: D efining groundwater system recharge and vulnerability areas in regions of suburban expansion; overview of thenorthern Illinois example. Abstracts with Programs - Geological Society of America 33, 45 only.

Carrasco, M .A. \& Barnosky, A.D. 2000: M IO M AP: a GIS-linked database to assess the effects of tectonic and climatic changes on mammalian evolution. Abstracts with Programs - Geological Society of America 32, 15 only.

Connelly, J.N ., van Gool, J.A.M . \& M engel F.C. 2000. Temporal evolution of a deeply eroded orogen: the N agssugtogidian orogen, W est Greenland. Canadian J ournal of Earth Sciences 37, 1121-1142.

Goodwin, P.B, Choiniere, M.E., H arris, F.W. \& D ean, B.P. 1996: Im- 
proving exploration with geographical information system (GIS) technology. American Association of Petroleum G eologists Bulletin 80, 1297.

H anmer, S., M engel, F., Connelly, ] \& van G ool, J. [A.M .] 1997: Significance of crustal-scale shear zones and syn-kinematic mafic dykes in the $\mathrm{N}$ agssugtogidian orogen, SW G reenland: a reexamination. Journal of Structural G eology 19, 59-75.

H arris, J.R., Wilkinson, K., H eather, K., Fumerton, S., Bernier, M .A., Ayer, J. \& Dahn, R. 2001: Application of GIS processing techniques for producing mineral prospectivity maps - A casestudy: mesothermal Au in the Swayze G reenstone Belt, O ntario, Canada. Natural Resources Research 10, 91-124.

Hollis, J.A., Keiding, M ., Stensgaard, B.M ., van G ool, J.A.M . \& Garde, A.A. 2006: Evolution of Neoarchaean supracrustal belts at thenorthern margin of theN orth Atlantic C raton, W est Greenland. In: Garde, A.A. \& Kalsbeek, F. (eds): Precambrian crustal evolution and Cretaceous-Palaeogenefaulting in West G reenland. G eological Survey of D enmark and Greenland Bulletin 11, 9-31 (this volume).

Kalsbeek, F. \& Nutman, A.P. 1996: Anatomy of the Early Proterozoic Nagssugtogidian orogen, West Greenland, explored by reconnaissance SH RIM P U -Pb dating. G eology 24, 515-518.

Knox-Robinson, C.M \& \& Weyborn, L.A.I. 1997: Towards a holistic exploration strategy: using geographic information systems (GIS) as a tool to enhanceexploration. Australian Journal of Earth Sciences 44, 453-463.

M anatschal, G., U lfbeck, D.\& van G ool, J. [A.M .] 1998. Changefrom thrusting to syncollisional extension at a mid-crustal level: an examplefrom the Palaeoproterozoic Nagssugtogidian orogen (West G reenland). Canadian J ournal of Earth Sciences 35, 802-819.

Marker, M., M engel, F., van G ool, J. \& field party 1995: Evolution of the Palaeoproterozoic N agssugtogidian orogen: D LC investigations in W est Greenland. Rapport Grønlands G eologiske U ndersøgelse 165, 100-105.

M azur, S., Piazolo, S. \& Alsop, G.I. 2006: Structural analysis of the northern Nagssugtogidian orogen, West Greenland: an example of complex tectonic patterns in reworked high-grade metamorphic terrains. In: Garde, A.A. \& Kalsbeek, F. (eds): Precambrian crustal evolution and $\mathrm{C}$ retaceous-Pal aeogene faulting in West $\mathrm{G}$ reenland. Geo- logical Survey of Denmark and Greenland Bulletin 11, 163-178 (this volume).

O lesen, N .Ø . 1984: Geological map of G reenland, 1:100 000, Agto 67 V.1 Nord. Copenhagen: Geological Survey of Greenland.

Piazolo, S., Alsop, G I., van G ool, J.A.M . \& Nielsen, B.M . 2004: Us ing $G I S$ to unravel high strain patterns in high grade terranes: a case study of indentor tectonics from West G reenland In: Alsop, G .I. et al. (eds.): Flow processes in faults and shear zones. G eological Society Special Publication (London) 224, 63-78.

Sørensen, K. 1983: G rowth and dynamics of the N ordre Strømfjord Shear Z one. Journal of $G$ eophysical Research 88, 3419-3437.

Sørensen, K., Glassley, W., Korstgård, J. \& Stensgaard, B.M. 2006: TheN ordreStrømfjord shear zone and the Arfersiorfik quartz diorite in Arfersiorfik, the N agssugtogidian orogen, West Greenland. In: Garde, A.A. \& Kalsbeek, F. (eds): Precambrian crustal evolution and Cretaceous-Palaeogen efaulting in W est Greenland. Geological Survey of D enmark and Greenland Bulletin 11, 145-161 (this volume).

True, M .A., Slawski, J.J. \& Hibner, B.A. 1999: Assessment of environmental hazards in western Siberian oil fields using remotely sensed imagery from U.S. and Russian national security systems. Proceedings of the Thematic Conference on Geologic R emote Sensing 13, 13-20.

van G ool, J.A.M . \& M arker, M. 2004: G eological map of Greenland, 1:100 000, U ssuit 67 V.2 N ord. Copenhagen: Geological Survey of Denmark and Greenland.

van Gool, J.A.M ., Connelly, J.N ., M arker, M . \& M engel, F.C. 2002: TheN agssugtogidian orogen of West $G$ reenland: tectonic evolution and regional correlations from a West $\mathrm{G}$ reenland perspective. Canadian J ournal of Earth Sciences 39, 665-686.

Vollmer, F.W. 1990: An application of eigenvaluemethods to structural domain analysis. Geological Society of America Bulletin 102, 786791.

Wilson, C.E., Scott, H .D ., N orman, R.J., Slaton, N .A. \& Frizzell, D.L. 2000: Spatial distribution of irrigation water quality parameters in Desha C ounty, Arkansas. Abstracts with Programs, Geological Society of America 32,45 only. 